\title{
Paracaval Lymph Node
}

National Cancer Institute

\section{Source}

National Cancer Institute. Paracaval Lymph Node. NCI Thesaurus. Code C117869.

A lymph node located adjacent to the lumbar region of the spine, along the right lateral aspect of the inferior vena cava. 